\title{
Analisis pengaruh investasi industri sektor primer, sektor sekunder dan sektor tersier terhadap pertumbuhan ekonomi di Provinsi Jambi
}

\author{
Nurhayani \\ Prodi Ekonomi Pembangunan, Fakultas Ekonomi dan Bisnis, Universitas Jambi \\ E-mail korespodensi: nurhayani@unja.ac.id
}

\begin{abstract}
The aims of this research are to determine the economic growth in Jambi Province and the factors that influence it. The variables of this research are economic growth, investment, primary industry sector investment, secondary industry sector investment, and tertiary industry sector investment as research variables. The research model is multiple linear analysis to determine the effect of primary, secondary and tertiary sector industry investment on economic growth in Jambi Province. Based on the regression result, only the research variable of realization of primary industry sector investment, which significantly influences economic growth in Jambi Province. While investment in secondary and tertiary industry sectors did not significantly affect economic growth in Jambi Province.
\end{abstract}

Keywords : Economic growth, Primary industry sector investment, secondary industry sector investment, and tertiary industry sector investment

\begin{abstract}
Abstrak
Penelitian ini bertujuan untuk mengetahui pertumbuhan ekonomi di Provinsi Jambi dan faktor-faktor yang mempengaruhi. Variabel dari penelitian ini adalah pertumbuhan ekonomi, investasi, investasi industri sektor primer, investasi industri sektor sekunder, dan investasi industri sector tersier sebagai variabel penelitian. Model penelitian adalah analisis linier berganda untuk mengetahui pengaruh investasi industri sektor primer, sekunder dan tersier terhadap pertumbuhan ekonomi di Provinsi Jambi. Berdasarkan hasil regresi, Hanya variabel penelitian investasi industri sektor primer, yang berpengaruh secara nyata terhadap pertumbuhan ekonomi di Provinsi Jambi. Sedangkan investasi industri sektor sekunder dan tersier tidak berpengaruh secara nyata terhadap pertumbuhan ekonomi di Provinsi Jambi.
\end{abstract}

Kata kunci: Pertumbuhan ekonomi, investasi, Investasi industri sektor primer, Investasi industri sektor sekunder, dan Investasi industri sektor tersier

\section{PENDAHULUAN}

Tingkat pertumbuhan ekonomi merupakan salah satu tolak ukur keberhasilan pembangunan suatu negara atau wilayah. Pada hakekatnya pembangunan itu merupakan rangkaian kegiatan dengan memanfaatkan seluruh potensi sebagai modal dasar yang kita miliki secara efektif dan efisien. Tingkat pertumbuhan ekonomi yang ditopang oleh lingkungan usaha yang mantap diharapkan dapat meningkatkan kemakmuran dan kesejahteraan bangsa. Pembangunan ekonomi adalah proses transformasi yang dalam perjalanan waktu ditandai oleh perubahan struktural, yaitu perubahan pada landasan kegiatan ekonomi maupun pada kerangka susunan ekonomi masyrakat yang 
bersangkutan(Djojohadikusumo,1994). Pertumbuhan ekonomi memperlihatkan bagaimana suatu perekonomian memberikan suatu pendapatan dalam masyarakat pada suatu periode tertentu dengan menggunakan faktor-faktor produksi dalam menghasilkan suatu output (Fauziana,2014). Investasi yang dilakukan oleh pemerintah, swasta dan pihak luar negeri pada prinsipnya ditujukan untuk meningkatkan lanu pertumbuhan ekonomi daerah tersebut. Pembangunan daerah dan pembangunan sektoral yang berlansung di daerah sesuai dengan potensi dan prioritas daerah. Menurut Ramli (2017); Das dan Raut (2014) terdapat tiga sektor yang dikembangkan oleh Fisher (1939) dan Clark (1940), sektor ekonomi terdiri dari tiga tahap utama produksi yaitu adalah yang primer, sekunder dan sektor tersier. Keterlibatan antar proporsi dari populasi bangsa dan ekonomi bangsa ditentukan oleh sektor-sektor ini.

Berdasarkan data dari Badan Pusat Statistik (2016) total investasi sektor industri dari tahun 2011 sampai dengan 2016 mengalami peningkatan setiap tahunnya, pad tahun 2016 tercatat sebesar Rp.16.846.000.000 sedangkan pertumbuhan ekonomi Provinsi Jambi pada tahun 2013 sebesar 6,84 persen dan pada tahun 2015 turun menjadi 4,21 persen. Berkembangnya sektor industri diharapkan dapat mendorong pertumbuhan ekonomi.

Pembangunan ekonomi pada dasarnya ditunjukkan untuk peningkatan pendapatan masyarakat. Kondisi ini tidak terlepas dari sejauh mana keberhasilan pembangunan ekonomi sebagai akibat adanya investasi yang dilakukan oleh berbagai pihak, baik pemerintah maupun swasta. Investasi dilakukan oleh pemerintah, swasta dan pihak luar negri dengan motivasi yang berbeda-beda. Tetapi pada prinsipnya ditunjukkan untuk meningkatkan laju pertumbuhan ekonomi daerah tersebut. Hanya untuk lebih produktif dan efisiennya penggunaan investasi tersebut haruslah diarahkan oleh pemerintah.

Peranan investasi terhadap pertumbuhan ekonomi telah lama ditelusuri oleh Harrod dan Domar dengan membangun suatu model berdasarkan pengalaman negara maju. Mereka memberikan peranan kunci kepada investasi di dalam proses pertumbuhan ekonomi, khususnya mengenai watak ganda yang dimiliki investasi melalui proses akselerasi dan proses multipier (Utama, 2013). Novita (2009) menjelaskan bahwa investasi di sektor pertanian atau sektor primer dianggap kurang memberikan keuntungan baik serta merupakan suatu kegiatan yang dianggap masih dan terus akan bersifat tradisional. Oleh sebagian pihak, pembangunan di sektor pertanian dianggap kurang dapat mempercepat kemajuan suatu negara. Sektor industrilah atau sektor sekunder yang dianggap sebagai sektor yang paling potensial dalam menghasilkan keuntungan serta mempercepat pertumbuhan ekonomi dan kemajuan suatu negara. Menurut Rusamana (2018), investasi sektor pertanian sektor industri dan sektor jasa berpengaruh nyata dan langsung terhadap pertumbuhan ekonomi indonesia. Ramli (2017) menyatakan bahwa negara yang berpendapatan rendah sering didominasi oleh sektor primer, negara yag berpendatan menengah didominasi oleh sektor sekunder dan negara-negara berpenghasilan tinggi didominasi oleh sektor tersier.

Pembangunan ekonomi daerah adalah suatu proses dimana pemerintah daerah dan masyarakatnya mengelola sumber daya yang ada dan membentuk suatu pola kemitraan antara pemerintah daerah dengan sektor swasta untuk menciptakan suatu lapangan kerja baru dan merangsang perkembangan pertumbuhan ekonomi dalam wilayah tersebut (Soebagiyo, 2015). Pembangunan daerah dan pembangunan sektoral dilaksanakan dengan selaras, sehingga pembangunan sektoral yang berlangsung didaerah disesuaikan dengan potensi dan prioritas daerah. Dengan dasar prinsip pembangunan nasional, daerah jambi dengan melakukan investasi haruslah mempertimbangkan kondisi dan potensi daerah. Perencanaan pembangunan ekonomi menjadi lebih penting untuk 
menghitung berapa besar pembentukan modal (investasi) yang dibutuhkan supaya mencapai laju pertumbuhan ekonomi yang telah ditetapkan. Investasi menjadi penting bagi pertumbuhan ekonomi terkait dengan kontribusi yang diberikannya. Kontribusi investasi terhadap pertumbuhan ekonomi bisa dilihat dari sisi permintaan dan penawaran. Dari sisi permintaan, peningkatan investasi menstimulasi petumbuhan ekonomi dengan menciptakan permintaan yang efektif. Berdasarkan sisi penawaran, peningkatan investasi merangsang pertumbuhan ekonomi dengan menciptakan lebih banyak cadangan modal yang kemudian berkembang dalam bentuk peningkatan kapasitas produksi (Sholihah, Syaparuddin, Nurhayani, 2017).

Chugtai (2014) menjelaskan bahwa Investasi Langsung Asing memiliki dampak signifikan pada pertumbuhan ekonomi di negara Pakistan. Hasilnya menunjukkan pentingnya FDI dan pertumbuhan ekonomi dengan proksi PDB dengan bukti kointegrasi antara variabel-variabel ini. Hasilnya juga menyajikan kausalitas jangka panjang antara FDI dan PDB sementara kausalitas dua arah jika ditemukan dalam jangka pendek. Secara keseluruhan tingkat sektoral,( industri bisnis sektor primer, sekunder dan tersier) dan terdapat signifikansi positif yang diidentifikasi antara FDI dan PDB . Alshehhi (2017) menyatakan bahwa Sektor tersier adalah salah satu gaya modern dari sistem ekonomi mengingat pangsa yang didudukinya di bidang produksi serta pangsa pekerjaan yang ditempati. Karenanya, seperti halnya tanah lain, UEA, menyaksikan perubahan struktural ekonomi yang serupa dengan negara-negara maju dan berkembang, di mana industri tersier menyumbang 55,4\% pada 2015 terhadap total pendapatan negara.sebagian besar industri berkontribusi signifikan terhadap pertumbuhan sektor tersier.

\section{METODE}

Jenis data yang digunakan adalah data sekunder periode waktu 2006 hingga 2016. Metode analisis data yang digunakan dalam peneltian ini adalah metode deskriptif dan metode kuantitatif. Metode analisis kuantitatif ini digunakan untuk menghitung angkaangka dari nilai pertumbuhan ekonomi di Provinsi Jambi berdasarkan time series periodes 2006-2016. Untuk mengetahui seberapa besar pengaruh dari Investasi industri sektor primer, investasi industri sektor sekunder, dan investasi industri sektor tersier terhadap pertumbuhan ekonomi di Provinsi Jambi digunakan model dasar dispesifikasi sebagai berikut:

$$
Y_{i}=\beta_{1}+\beta_{2} X_{2 i}+\beta_{3} X_{3 i}+\ldots . .+\beta_{n} X_{n i}+\mu_{i}
$$

Berdasarkan spesifikasi model diatas selanjutnya di formulasikan model yang akan di estimasi dengan menggunakan metode Ordinary Least Square (OLS) atau metode kuadrat terkecil biasa dalam bentuk persamaan otomatis dapat ditulis persamaan regresinya sebagai berikut :

$$
P E_{t}=\beta_{1}+\beta_{2} I p_{t}+\beta_{3} I s_{t}+\beta_{4} I t_{t}
$$

Sedangkan Analisis deskriptif adalah yang menginterpretasikan data dengan mengambil kesimpulan dari data dalam bentuk angka yang sudah ada kedalam bentuk tulisan untuk mengacu kepada pengambilan keputusan. Metode ini hanya merumuskan dan mengumpulkan data serta menginterpretasikan sehingga memberikan suatu keterangan atau gambaran yang ada. Adapun model pencarian perkembangan pertumbuhan ekonomi menggunakan rumus:

$$
\Delta P E(t)=\frac{P E(t)-P E(t-1)}{P E(t-1)} \mathrm{X} 100
$$




\section{HASIL DAN PEMBAHASAN}

Analisis pada penelitian ini dilakukan dengan menggunakan data sekunder yang diperoleh dari berbagai sumber dalam bentuk tahunan selama periode 2006-2016. Sesuai dengan model yang digunakan yaitu analisis regresi linier berganda, mengenai hubungan antara variabel terikat (dependen) yaitu PDRB provinsi Jambi dengan variabel bebas (Independent) yaitu IP adalah investasi sektor primer, IS adalah investasi sektor sekunder, dan IT adalah investasi sektor tersier. Pengolahan data dilakukan dengan menggunakan E-views berdasarkan data yang diperoleh selama kurun waktu 10 tahun. Untuk mengetahui bagaimana pengaruh variabel independen terhadap variabel dependen maka dilakukan estimasi sebagai berikut, dimana persamaanya adalah :

PDRB $=-5315.014+708.5577 \mathrm{IPt}+-706.4465 \mathrm{ISt}+1320.934 \mathrm{ITt}$

$\begin{array}{llll}\text { t-hitung } & =(-12.80993) \\ \text { F-hitung } & =267.4770 \\ \text { Prob. F-hitung } & =0,000000 \\ \mathrm{R}^{2} & =0,991352 \\ \text { Adj R } & =0,987646\end{array}$

Dimana :
PDRB $=$ PDRB provinsi Jambi
IP $\quad=$ Investasi Sektor Primer
IS $\quad=$ Investasi Sektor Sekunder
IT = Investasi Sektor Tersier

Secara parsial Investasi Sektor Primer berpengaruh signifikan terhadap Pertumbuhan ekonomi Provinsi Jambi (nilai t-hitung 3,060030>1,889458 sehingga $\mathrm{H}_{0}$ ditolak), Investasi Industri Sektor Sekunder tidak berpengaruh signifikan terhadap Pertumbuhan Ekonomi Jambi (nilai t-hitung -0,662615 < 1,89458 sehingga $\mathrm{H}_{0}$ diterima) dan Investasi Industri Sektor Tersier tidak berpengaruh signifikan terhadap Pertumbuhan Ekonomi Jambi (nilai t-hitung 1,334070 $<1,89458$ sehingga $\mathrm{H}_{0}$ diterima). Secara Simultan, investasi sektor primer, sektor sekunder dan sektor tersier secara bersama - sama berpengaruh terhadap pertumbuhan ekonomi Provinsi Jambi periode $2006-2016$.

\section{KESIMPULAN DAN SARAN}

\section{Kesimpulan}

Berdasarkan dari hasil analisis deskriptif dan pembahasan sebelumnya, maka di peroleh kesimpulan bahwa Secara rata-rata selama periode 2006-2016 laju perkembangan realisasi investasi sektor primer 8,858 persen, realisasi investasi sektor sekunder 5,008, realisasi investasi sektor tersier 4,496 persen dan pertumbuhan ekonomi di Provinsi Jambi adalah sebesar 7,307persen pertahun.

Pada tingkat kepercayaan tertentu $(\alpha=5 \%)$ Hanya variabel penelitian realisasi investasi sektor primer, yang berpengaruh secara nyata terhadap pertumbuhan ekonomi di Provinsi Jambi, Sedangkan investasi industri sektor sekunder dan tersier tidak berpengaruh secara nyata terhadap pertumbuhan ekonomi di Provinsi Jambi.

\section{Saran}

Berdasarkan hasil penelitian dan kesimpulan yang di dapat, maka saran yang dapat diberikan oleh peneliti pada penelitian ini, yaitu pemerintah daerah diharapkan 
dapat meningkatkan investasi industri sektor primer di Provinsi Jambi melalui industri yang menghasilkan barang atau benda yang tidak perlu pengolahan lebih lanjut. Barang atau benda yang dihasilkan tersebut dapat dinikmati atau digunakan secara langsung. Seperti: industri anyaman, industri konveksi, industri makanan dan minuman sehingga dapat meningkatkan pertumbuhan ekonomi di Provinsi Jambi. Pemerintah daerah juga diharapkan dapat meningkatkan investasi industry sektor sekunder di Provinsi Jambi melalui industri yang menghasilkan barang atau benda yang membutuhkan pengolahan lebih lanjut sebelum dinikmati atau digunakan. Seperti: industri pemintalan benang, industri ban, industri baja, dan industri tekstil sehingga dapat meningkatkan pertumbuhan ekonomi di Provinsi Jambi.

\section{DAFTAR PUSTAKA}

Ahmad, K. (2004). Dasar-Dasar Manajemen Investasi dan Portofolio. Rineka Cipta: Jakarta.

Alshehhi, Y.Z., \& POPP, J. (2017). Sectoral Analysis: Growth Accounting of Tertiary Industries. SEA -Practical Application of Science, V(14), 221-230.

Anoraga, P. (1995). Perusahaan Multi Nasional dan PMA PT. Dunia Pustaka Jaya: Jakarta

Boediono. (1992). Ekonomi Moneter. Edisi Ketiga, BPFE-UGM: Yogyakarta.

Boediono. (1995). Ekonomi Makro Edisi Empat. BPFE-UGM:Jakarta

Chughtai, M,W. (2014). Effectiveness of Foreign Direct Investment on Economic Growth in Pakistan: A Policy Perspective Approach. AUDOE, 10(4), 159-175.

Das., Lawly, R., \& Rajesh. (2014). Impact of Changes in Service Sector in India in Shaping The Future of Business \& Society. Procedia Economics And Finance 11(2014), $795-803$.

Djojohadikusuma, S. (1994). Perkembangan Pemikiran Ekonomi Dasar Teori Perumbuhan dan Ekonomi Pembangunan. PT. Ikrar Mandiri Abadi: Jakarta

Dumairy. (1997). Perekonomian Indonesia, Erlangga: Jakarta

Fauziana,L.,dkk. (2014). Keterkaitan Investasi Modal terhadap GDP Indonesia. Journal Economics Development Analysis.3(2), 372-380.

Hill, H. (1990). Investasi Asing dan Industrialisasi di Indonesia. Terjemahan Burhanuddin Abdullah. LP3ES: Jakarta.

Istiqomah, L., Umiyati, E., \& Hardiani, H. (2018). Pengaruh Modal dan Tenaga Kerja Terhadap Nilai Produksi Industri Pisang Salai di Desa Purwobakti Kecamatan Bathin III Kabupaten Bungo. e-Jurnal Ekonomi Sumberdaya dan Lingkungan 7 (1), 43-55

Jhingan, M.L. (2000). Ekonomi Pembangunan dan Perencanaan. PT. Raja Grafindo Persada: Jakarta.

Kamaludin, R. (1991). Beberapa Aspek Pelaksanaan Kebijaksanaan Pembangunan Daerah. FE UI: Jakarta.

Kusumosuwidho, S. (1990). Pengantar Ekonomi Mikro. PT. Raja Grafindo Persada: Jakarta.

Mar'atus, S. I, Syaparuddin, S., \& Nurhayani, N. (2017). Analisis Investasi Sektor Industri Manufaktur, Pengaruhnya Terhadap Pertumbuhan Ekonomi dan Penyerapan Tenaga Kerja di Indonesia. Jurnal Paradigma Ekonomika 12 (1), 1124

Novita, D. (2009). Dampak Investasi Sektor Pertanian Terhadap Perekonomian Sumatera Utara. Jurnal Perencanaan \& Pengembangan Wilayah, 4(3), 131-141. 
Ramli, N.A., \& Nartea, G. (2017). Interrelation between Economic Sectors, Capital Structure and A Firm's Financial Performance: The Indonesian Evidence, International Journal of Economics and Financial, 7(5), 380 - 388.

Rusmana, A. (2018). Pengaruh Investasi Sektor Pertanian dan Investasi Sektor Industri Serta Investasi Sektor Jasa Terhadap Pertumbuhan Ekonomi dan Tingkat Pengangguran di Indonesia. Jurnal Ilmu Ekonomi Mulawarman, 3(4), 1-18

Setyowati, T.M. (2015). Analisis Pengaruh Investasi Sektor Transportasi Terhadap Pertumbuhan Ekonomi Indonesia Tahun 2004 - 2013. Jurnal Manajemen Bisnis Transportasi dan Logistik, 1(3), 524-551

Sholihah., Irma. M., Syaparuddin., \& Nurhayani. (2017). Analisis Investasi Sektor Industri Manufaktur, Pengaruhnya Terhadap Pertumbuhan Ekonomi dan Penyerapan Tenaga Kerja di Indonesia. Jurnal Paradigma Ekonomika, 12(1), 11- 24.

Sukirno, S. (2002). Pengantar Teori Makro Ekonomi. LPFE-UI: Jakarta.

Utama, M.S. (2013). Potensi dan Peningkatan Investasi di Sektor Pertanian dalam Rangka Peningkatan Kontribusi Terhadap Perekonomian di Provinsi Bali. Buletin Studi Ekonomi, 18(1), 51-57.

Yulmardi, Y., \& Erfit.E. (2018). Daya Saing Sektor Pertanian dalam Mendorong Pembangunan Pertanian di Provinsi Jambi. Jurnal Paradigma Ekonomika 13 (2), $65-76$ 